\title{
Characterization and Purification of Neoplastic Cells of Nodular Lymphocyte Predominant Hodgkin Lymphoma from Lymph Nodes by Flow Cytometry and Flow Cytometric Cell Sorting
}

\author{
Jonathan R. Fromm, ${ }^{*}$ Anju Thomas, ${ }^{\dagger}$ and Brent L. Wood ${ }^{*}$
}

From the Department of Laboratory Medicine, * University of Washington; and Phenopath Laboratories, ${ }^{\dagger}$ Seattle, Washington

Accepted for publication October 18, 2016.

Address correspondence to Jonathan R. Fromm, M.D., Ph.D., University of Washington Medical Center, Box 357110 , 1959 NE Pacific St., Seattle, WA 98195. E-mail: jfromm@u. washington.edu.

\begin{abstract}
We report the flow cytometric (FC) identification and characterization of lymphocyte predominant (LP) cells from tissues involved by nodular lymphocyte predominant Hodgkin lymphoma (NLPHL). First, we immunophenotyped the NLPHL cell line (DEV) confirming a germinal center immunophenotype, lack of expression of CD32 and CD58, and expression of CD54. Nineteen of 26 lymph nodes involved by NLPHL demonstrated a population with an LP immunophenotype (73\%), which included expression of germinal center markers (CD75/Bcl-6-positive, CD32-weak/negative without CD10), a B-cell immunophenotype $\left(C D 19 / C D 20 / C^{2} 40^{+}\right), I g D$ and/or IgM expression (67\%), and lack of programmed death-ligand $1 /$ ligand 2. The LP cells demonstrated an adhesion macromolecule expression pattern distinct from Hodgkin and Reed-Sternberg cells of classical Hodgkin lymphoma (CHL) (uniform CD50 and variable CD58 for NLPHL; minimal CD50, bright CD58 expression for $\mathrm{CHL}$ ). A two-tube consensus assay identified LP cells in all seven NLPHL cases examined and only one non-NLPHL case (94 cases evaluated). Finally, FC cell sorting studies confirm that FC-defined populations have an LP cytomorphology. Taken together, these findings demonstrate a two-tube consensus assay can be used to immunophenotype NLHPL with high specificity and sensitivity and rapidly purify LP cells for genetic studies. This study also confirms aneuploidy in LP cells, provides antigens that may be helpful in distinguishing NLPHL from CHL, and suggests that T cells interact less avidly with LP cells than with Hodgkin and Reed-Sternberg cells. (Am J Pathol 2017, 187: 304-317; http://dx.doi.org/10.1016/j.ajpath.2016.10.007)
\end{abstract}

Nodular lymphocyte predominant Hodgkin lymphoma (NLPHL) is an uncommon type of B-cell lymphoma, characterized by the presence of scattered, rare, large neoplastic germinal center B cells [lymphocyte predominant (LP) cells] embedded in a nodular, reactive infiltrate that includes small, non-neoplastic lymphocytes and histiocytes. $^{1,2}$ In immunohistochemical sections, critical for making a pathologic diagnosis, the LP cells express CD20 and Pax-5 (pan-B-cell markers), CD45 (pan-hematopoietic marker), Bcl-6 (marker of germinal center origin) without expression of CD3 (pan-T-cell marker), CD15 (granulocyte marker), or CD30 (lymphoid activation marker). ${ }^{1-3}$ Lack of CD15 and CD30 is particularly important because the neoplastic cells of the related neoplasm, classical Hodgkin lymphoma (CHL), express these antigens. ${ }^{4-6}$
Flow cytometry is a technique in which a cell suspension is placed in a moving fluid stream. ${ }^{7}$ The resulting individual cells are directed through a flow cell where the cells can be interrogated by laser-excitation of fluorochrome-conjugated antibodies bound to cell surface, cytoplasmic, or nuclear antigens, allowing for measurement of antigen expression. ${ }^{7,8}$ Although analogous to immunohistochemistry, flow cytometry affords the evaluation of multiple antigens on/in cells interpreted in the context of their light scatter properties. ${ }^{7}$ Today, flow cytometry is helpful in making the diagnosis of leukemia and lymphoma. We have shown that

Supported by the Department of Laboratory Medicine, University of Washington.

Disclosures: None declared. 
flow cytometry and flow cytometric cell sorting (FCCS) can be used to diagnosis $\mathrm{CHL}^{9-11}$ and to purify the neoplastic Hodgkin and Reed-Sternberg (HRS) cells of CHL. ${ }^{12,13}$

T-cell-Hodgkin cell rosettes are observed in tissue sections of CHL and NLPHL and provide a diagnostic characteristic of these lymphomas. ${ }^{1,4,14-18} \mathrm{We}$ and others have demonstrated that the rosettes of CHL are mediated by CD54 and CD58 on the HRS cells binding to their adhesion binding partners (lymphocyte function-associated antigen-1 and CD2) on the T cells. ${ }^{12,19}$ These interactions are useful to help diagnose CHL by flow cytometry and can be directly observed by FCCS. ${ }^{10,12,13}$ However, what mediates the interaction of LP cells to T cells is unknown.

The intent of this study was to provide the identification and characterization of neoplastic LP cells of NLPHL by flow cytometry, affording a novel method to suggest the diagnosis of NLPHL, rapidly purify viable LP cells for further study, and evaluate antigen expression of these cells.

\section{Materials and Methods}

\section{Cell Line}

The NLPHL cell line $\mathrm{DEV}^{20,21}$ was a generous gift from Dr. Anke van den Berg (University of Groningen, the Netherlands). The cell line was cultured in RPMI 1640 (Gibco BRL, Grand Island, NY) supplemented with $20 \%$ fetal bovine serum, $1 \%$ glutamine, $1 \%$ penicillin, and $1 \%$ streptomycin at $37^{\circ} \mathrm{C}$ in $5 \% \mathrm{CO}_{2}$ for use in immunophenotypic studies.

\section{Fluorescently Labeled Antibodies and Controls}

For all experiments, flow cytometric studies were performed on a modified 4-laser, 10-color Becton Dickinson (Franklin Lakes, NJ) LSRII flow cytometer using the following laserfluorochrome combinations: i) $405 \mathrm{~nm}$ violet laser (one color) - Pacific Blue or DAPI; ii) $488 \mathrm{~nm}$ blue laser (five colors) - fluorescein isothiocyanate (FITC), phycoerythrin (PE), PE-Texas Red (electron coupled dye/PE-TR), PEcyanine-5 (PE-Cy5) or PE-cyanine-5.5 (PE-Cy5.5), and $\mathrm{PE}-$ cyanine-7 (PE-Cy7); iii) $594 \mathrm{~nm}$ yellow laser (one color) - Alexa Fluor 594 (A594); and iv) 633 nm red laser (three colors) - allophycocyanin (APC), APC-Alexa Fluor 700 (APC-A700), and APC-Cy7. The specific fluorescently labeled antibodies used in this study are listed in Table 1. Fluorescence minus one controls were run to determine background staining.

\section{Immunophenotyping of DEV Cells}

For surface immunophenotyping (performed at room temperature in the dark), 10,000 to $100,000 \mathrm{DEV}$ cells were incubated with fluorescently labeled antibodies for 15 minutes in $0.1 \mathrm{~mL}$ RPMI. Cells suspensions were lysed and fixed with $0.25 \%$ paraformaldehyde, $0.15 \mathrm{~mol} / \mathrm{L}$ ammonium chloride, pH 4.8 for 15 minutes, washed with $3 \mathrm{~mL}$ phosphate-buffered saline and bovine serum albumin (PBS-BSA), and incubated with $0.1 \mathrm{~mL}$ of 1:10 DAPI in PBS to exclude nonviable cells before analysis. For combined cell surface and nuclear immunophenotyping, cells were incubated for 15 minutes with surface-reactive labeled antibodies, washed twice, incubated for 15 minutes with $0.1 \mathrm{~mL}$ of Invitrogen (Carlsbad, CA) Fix and Perm reagent A, and washed twice. After the addition of $0.1 \mathrm{~mL}$ of Invitrogen Fix and Perm reagent B, cells were washed twice, incubated for 60 minutes with antibodies to nuclear antigens (Bcl-6), washed, and analyzed. For DNA index experiments, the cells were incubated with $0.1 \mathrm{~mL}$ of DAPI solution $(2.5 \mathrm{mg} / \mathrm{mL})$ after the final washing step. DNA indices are calculated using reference normal $G_{1}$ and $G_{2} M$ fractions.

\section{Preparation of Lymph Node Specimens for Flow Cytometry}

This study was conducted with approval of the University of Washington Human Subjects Review Committee. Lymph node biopsy specimens were collected from April 2005 to July 2013, and the corresponding paraffin-embedded tissue diagnoses were rendered with a combination of hematoxylin and eosin morphologic examination and immunohistochemistry at the University of Washington/Seattle Cancer Care Alliance. Fresh lymph node suspensions were prepared in a manner identical to that used for clinical studies and is described elsewhere. ${ }^{12}$

Ten-color flow cytometric tubes were prepared after clinical flow cytometric evaluation on morphologically confirmed NLPHL (diagnosed by tissue section morphologic examination and immunohistochemistry ${ }^{1,2}$ ). Experiments used 50,000 to 500,000 cells in $0.1 \mathrm{~mL}$ per tube and were stained with labeled antibodies in a manner described above (for DEV). The specific combinations in the initial phase of the work varied, based on the amount of cell suspension available. Combinations included backbone antibodies [three to four antibodies that invariantly recognize antigens present on LP cells (CD20, CD40, and CD71)], one pan-T-cell antigen (CD5), one macrophage antigen (CD64), and CD45 to which a variety of other investigational antibodies were added. When a putative LP population was present, it was additionally evaluated for the expression of CD15, CD30, and CD95, using our clinical assay for CHL. ${ }^{12,13}$ Subsequently, consensus tubes were designed for routine immunophenotyping of NLPHL (Table 2) and evaluated using seven additional NLPHL specimens and 94 tissues (reactive, involved by $\mathrm{CHL}$, or involved by various non-Hodgkin lymphomas).

\section{Criteria for Identifying LP Cells}

From the known immunophenotype of LP cells in paraffin section $^{1-3}$ and our previous work with immunophenotyping $\mathrm{CHL}^{9-11}$ the following criteria were required for the identification of an LP population: i) LP cells are large and 
Table 1 Antibodies Used in the Study

\begin{tabular}{|c|c|c|c|}
\hline Antigen & Fluorochrome & Vendor & Clone \\
\hline HLA-ABC & FITC & Beckman Coulter (Immunotech; Hialeah, FL) & B9.12.1 \\
\hline HLA-DR & FITC & BD Biosciences (San Jose, CA) & L243 \\
\hline Ig light chains $\kappa-\lambda$ & FITC/PE & BD Biosciences & TBC-8-2/1-155-2 \\
\hline $\operatorname{IgA}$ & $\mathrm{PE}$ & Miltenyi (San Diego, CA) & IS11-8E10 \\
\hline IgD & FITC/PE Cy7 & BD Pharmingen (San Jose, CA)/BioLegend (San Diego, CA) & IA6-2 \\
\hline $\operatorname{Ig} M$ & $\mathrm{FITC} / \mathrm{PB}$ & BD Pharmingen/BioLegend & G20-127/MHM-88 \\
\hline CD2 & FITC & BD Biosciences & S5.2 \\
\hline CD3 & $\mathrm{FITC} / \mathrm{PE}$ & BD Biosciences & SK7 \\
\hline CD4 & $\mathrm{PE}$ & BD Biosciences & SK3 \\
\hline CD5 & PE-TR (ECD) & Beckman Coulter & $\mathrm{BL} 1 \mathrm{a}$ \\
\hline CD7 & APC & Thermo Fisher Scientific (Waltham, MA) & CD7-6B7 \\
\hline CD11 c & APC & Miltenyi Biotec & MJ4-27G12.4.6 \\
\hline CD13 & $\mathrm{PE}$ & BD Biosciences & L138 \\
\hline CD14 & PE Cy5.5 & Beckman Coulter & RM052 \\
\hline CD15 & $\mathrm{APC}$ & BD Biosciences & HI98 \\
\hline CD16 & A647 & BD Pharmingen & $3 G 8$ \\
\hline CD18 & FITC & BD Biosciences & $\mathrm{L} 130$ \\
\hline CD19 & PE-TR/PECy7 & Beckman Coulter (Immunotech) & J4.119 \\
\hline CD20 & V450 & BD Biosciences & L27 \\
\hline CD20 & $\mathrm{Pe}-\mathrm{Cy} 7 / \mathrm{APC}-\mathrm{H} 7$ & Beckman Coulter/BD Biosciences & B9E9/L27 \\
\hline CD21 & FITC & Beckman Coulter & BL13 \\
\hline CD22 & $\mathrm{PE}$ & Beckman Coulter & $\mathrm{SJ} 10.1 \mathrm{H} 11$ \\
\hline CD33 & PE-Cy7 & BD Biosciences & P67.6 \\
\hline CD34 & ECD & Beckman Coulter (Immunotech) & 581 \\
\hline CD36 & FITC & BD Biosciences & CB38 (NL07) \\
\hline CD38 & PE/A594 & BD Biosciences & HB7 \\
\hline CD40 & PE Cy5.5 & Beckman Coulter & MAB89 \\
\hline CD43 & APC & Thermo Fisher Scientific & L10 \\
\hline CD44 & FITC & BD Biosciences & L178 \\
\hline CD45 & $\mathrm{APC}-\mathrm{H} 7$ & BD Biosciences & 2D1 \\
\hline CD45 R0 & PE & Beckman Coulter (Immunotech) & UCHL-1 \\
\hline CD45RA/B220 & FITC & Beckman Coulter (Immunotech) & ALB11 \\
\hline CD47 & FITC & BD Biosciences & $\mathrm{B} 6 \mathrm{H} 12$ \\
\hline CD48 & PB/FITC & Exbio (Czech Republic)/BD Biosciences & MEM-102/TU145 \\
\hline CD50* & Unlabeled/PeCy7 & eBioscience (San Diego, CA) & CBR-IC3/1/M1-14D12 \\
\hline CD50 & PE & BioLegend & CBR-IC3/1 \\
\hline CD52 & APC & Invitrogen & CD1D12 \\
\hline CD54 & PE/APC & Invitrogen/BioLegend & MEM-111/HA58 \\
\hline CD56 & PECy7 & Beckman Coulter & N901 (NKH-1) \\
\hline CD57 & FITC & BD Biosciences & HNK-1 \\
\hline CD58 & $\mathrm{PE}$ & Beckman Coulter (Immunotech) & AICD58 \\
\hline CD62L & FITC & Beckman Coulter (Immunotech) & Dreg 56 \\
\hline CD64 & FITC & Beckman Coulter (Immunotech) & 22 \\
\hline
\end{tabular}


Table 1 (continued)

\begin{tabular}{|c|c|c|c|}
\hline Antigen & Fluorochrome & Vendor & Clone \\
\hline CD66b & FITC & Beckman Coulter (Immunotech) & $80 \mathrm{H} 3$ \\
\hline CD70 & FITC & BD Biosciences & $\mathrm{Ki}-24$ \\
\hline CD74 & $\mathrm{PE}$ & BioLegend & LN2 \\
\hline $\mathrm{CD}^{\dagger} 5^{\dagger}$ & BIOTIN/V450 & BioLegend/BD Biosciences & LN1 \\
\hline CD75 & FITC & BD Biosciences & LN1 \\
\hline CD79b & APC & Beckman Coulter & HM47 \\
\hline CD80 & $\mathrm{PE} / \mathrm{PE}-\mathrm{CY} 7$ & BD Biosciences/BioLegend & L307.4/2D10 \\
\hline CD81 & FITC & BD Biosciences & TAPA-1 \\
\hline CD83 & $\mathrm{PE} / \mathrm{APC}$ & BD Biosciences & HB15e \\
\hline CD86 & $\mathrm{PE}$ & BD Biosciences & 2331 (FUN-1) \\
\hline CD102 & $\mathrm{PE}$ & BioLegend & CBR-IC2/2 \\
\hline CD103 & FITC & BD Pharmingen & Ber-ACT8 \\
\hline CD117 & PECy5 & Beckman Coulter (Immunotech) & $95 C 3$ \\
\hline CD123 & $\mathrm{PE}$ & BD Biosciences & $9 \mathrm{F5}$ \\
\hline CD126 & $\mathrm{PE}$ & BD Pharmingen & M5 \\
\hline CD127 & $\mathrm{PE}$ & BD Pharmingen & HIL-7R-M21 \\
\hline CD133 & APC & Miltenyi & $\mathrm{AC} 133$ \\
\hline CD135 & $\mathrm{PE}$ & BD Pharmingen & $4 \mathrm{G} 8$ \\
\hline CD138 & APC & BD Biosciences & MI15 \\
\hline CD158a & FITC & BD Biosciences & HP-3E4 \\
\hline CD158b & PE & Beckman Coulter & GL183 \\
\hline $\mathrm{CD} 274$ & PE-Cy7 & eBioscience & MIH1 \\
\hline $\operatorname{CD} 275^{*}$ & Unlabeled/APC & BD Biosciences/BioLegend & 2D3/P0LY4053 \\
\hline $\mathrm{BCL}-6$ & PE & BD Pharmingen & K112-91 \\
\hline CXCR3 & A488 & BD Pharmingen & $\mathrm{IC} 6 \backslash \mathrm{CXCR} 3$ \\
\hline CXCR4 & A488 & BD Pharmingen/BioLegend & $\mathrm{I} 2 \mathrm{G} 5$ \\
\hline CXCR5 & FITC & BD Pharmingen & RF8B2 \\
\hline CCR5 & $\mathrm{PE}$ & BD Pharmingen & $2 \mathrm{D} 7 \backslash \mathrm{CCR} 5$ \\
\hline CCR6 & $\mathrm{PE}$ & BD Pharmingen & $11 \mathrm{~A} 9$ \\
\hline CCR7 & PE & BD Pharmingen & 3D12 \\
\hline EPCAM & FITC & BD Biosciences & EBA-1 \\
\hline
\end{tabular}

${ }^{*}$ Antibody/fluorochrome conjugate was generated using an unlabeled primary antibody and fluorochrome-labeled secondary antibody.

${ }^{\dagger}$ Antibody/fluorochrome conjugate was generated using a biotin-labeled antibody and streptavidin labeled with the indicated fluorochrome.

A488, Alexa Fluor 488; A594, Alexa Fluor 594; A647, Alexa Fluor 647; A700, Alexa Fluor 700; APC, allophycocyanin; Cy5.5, cyanine-5.5; Cy7, cyanine 7; DR, antigen D-related; ECD, electron coupled dye; EPCAM, epithelial cell adhesion molecule; FITC, fluorescein isothiocyanate; HLA, human leukocyte antigen; L, ligand; PB, Pacific Blue; PE, phycoerythrin; TR, Texas Red.

thus should have increased forward and side light scatter compared with small lymphocytes; ii) the immunophenotype should be similar to that observed for DEV and in paraffin section with expression of $\mathrm{CD} 20^{1-3}$ and $\mathrm{CD} 40^{22,23}$; iii) the cells may be immunoglobulin light chain restricted $^{24,25}$; iv) the cells should be of germinal center origin $\left(\mathrm{Bcl}-6^{+},{ }^{1-3}\right.$ and $\left.\mathrm{CD} 75^{+26}\right)$ but without expression of $\mathrm{CD} 10^{3,27}$ and; v) a putative LP population will form a distinct cluster of events in multidimensional flow cytometric space. 
Table 2 Combinations Used in NLPHL Consensus Tubes

\begin{tabular}{lllllllllll}
\hline Fluorochrome & V450 & FITC/A488 & PE & ECD & PE-Cy5.5 & PE-Cy7 & A594 & APC & APC-A700 & APC-H7 \\
\hline Tube 1 & CD75 & CD64+CD10 & CD32 & CD5 & CD40 & CD20 & CD38 & CD54 & CD71 & CD45 \\
Tube 2 & DAPI & CD64 & BCL-6 & CD5 & CD40 & CD10 & CD38 & CD54 & CD71 & CD20 \\
\hline
\end{tabular}

A488, Alexa Fluor 488; A594, Alexa Fluor 594; A700, Alexa Fluor 700; APC, allophycocyanin; Cy5.5, cyanine-5.5; Cy7, cyanine 7; ECD, electron coupled dye; FITC, fluorescein isothiocyanate; NLPHL, nodular lymphocyte predominant Hodgkin lymphoma; PE, phycoerythrin.

\section{Flow Cytometry Combinations Used for FCCS Experiments}

The antibody combinations used in the FCCS sorting experiments are as follows: i) CD75-V450, CD64-FITC, CD77-PE, CD5-PE-TR, CD40-PE-Cy5.5, CD83-APC, CD71-APCA700, CD20-APC-Cy7; ii) CD95-PB, CD64-FITC, CD32-PE, CD5-PE-TR, CD40-PECy5.5, CD54-APC, CD71-APCA700, CD20-APC-Cy7; iii-vi) CD75-V450, CD64-FITC, CD32-PE, CD5-PE-TR, CD40-PE-Cy5.5, CD54-APC, CD71APC-A700, CD20 APC-Cy7.

\section{FCCS of Lymph Nodes Involved by NLPHL}

Cells from the lymph node suspension of six NLPHL cases were stained with the antibody combinations (above) in 1 $\mathrm{mL}$ of PBS-BSA (15 minutes at room temperature), washed once with PBS-BSA, reconstituted in 1 to $2 \mathrm{~mL}$ of RPMI, and sorted using a FACSAria II flow cytometric cell sorter (Becton Dickinson). The sorted cells were concentrated by centrifugation, Wright-Giemsa stained, and examined by light microscopy. For five sorted cases, an aliquot of the sorted cells was run on the cell sorter to measure purity of the sorted LP cell fraction.

\section{Results}

\section{Flow Cytometric Studies of DEV}

In an effort to identify antigens useful for identification of LP cells from lymph nodes, we immunophenotyped the NLPHL cell line DEV. ${ }^{20,21}$ DEV expressed pan-B-cell antigens (CD19, CD20, CD45R/B220, and CD79b) and brightly expressed CD40 (B-cell-associated antigen); no expression of CD32 (FcrRIIb) was identified. DEV expressed CD75 (germinal center-associated marker), nuclear Bcl-6, but not CD10, in accord the immunophenotype identified in paraffin sections. ${ }^{1,3}$ Likewise, immunoglobulin heavy chains $(\operatorname{IgH})$ were not expressed. T-cell and myeloid antigens (including CD15) were not expressed. Activation antigens (CD30, CD70, and CD71) were expressed, as were adhesion macromolecules (CD48, CD50, CD54, and CD102). However, the adhesion macromolecule CD58 (important in the interaction of HRS cells with $\mathrm{T}$ cells ${ }^{12,19}$ ) was absent. Finally, given current interest in tumor immunotherapy directed at PD-1, ${ }^{28,29}$ we evaluated expression of PD-L1 (CD274), PD-L2 (CD273), and the related B7 molecule, B7-H2 (inducible T-cell costimulator ligand; CD275); CD273 and CD275 were expressed, whereas CD274 was not present on DEV cells (Table 3).

\section{Identification of LP Cells in Tissues by Flow Cytometry}

A total of 26 lymph nodes confirmed by morphologic examination to be NLPHL were immunophenotyped in the initial phase of the study (using a variety of antibody combinations); an LP population was identified in 19 examinations $(73 \%)$. LP populations were small in size, ranging from $0.0002 \%$ to $0.25 \%$ of the leukocytes (Table 4 , and Figures 1 and 2).

Our prior work with CHL demonstrated that T-cell and HRS cell rosettes can be readily identified on a plot of CD45 versus CD5, with the rosetted fraction of HRS cells being those cells with evidence of CD5 expression. ${ }^{10,12,13}$ With the use of such an approach, we observed rosettes in $50 \%$ of cases ( 9 of 18 cases) of NLPHL examined. For comparison, 20 consecutive CHL cases, previously immunophenotyped as part of routine clinical care, were re-examined, with $90 \%$ showing rosette formation, suggesting that LP cells interact with less avidity than HRS cells with $T$ cells (under the conditions of flow cytometric experiments).

\section{B-Cell-Associated Antigens}

For NLPHL cases for which a putative LP population were identified, intensity of antigen expression was scored on a semiquantitative scale as follows: 0 , negative (no expression); 1, low or dim; 2, moderate; and 3, bright expression. Mean antigen intensity (MAI) was calculated across all the cases in which the antigen was measured. When possible, antigen expression was also compared with normal cells in the specimen. As expected, the putative LP populations expressed B-cell antigens; CD19 and CD20 were expressed in almost all cases, with intensities varying from between weak and moderate for CD19 (MAI = 1.6) and between moderate and bright expression for CD20 (MAI $=2.2$ ). CD19 was at, and CD20 typically above, the expression seen in normal small B cells. CD40 was moderately to brightly expressed on the LP cells (MAI $=2.4$ ) in all 19 cases, usually at a level higher than the small B cells. The germinal center B-cell-associated marker CD75 was weakly to moderately expressed (MAI $=1.8$ ), usually showing a variable pattern, similar to that observed in reactive germinal centers (data not shown). BCL-6 showed nuclear expression at a weak-to-moderate level (MAI $=1.7)$, whereas CD10 
Table 3 Expression of Antigens in Hodgkin Cell Line (DEV) as Determined by Flow Cytometry

\begin{tabular}{|c|c|}
\hline Antigen & DEV expression ${ }^{* \dagger}$ \\
\hline \multicolumn{2}{|c|}{ B-cell-associated antigens } \\
\hline HLA-DR & - \\
\hline Ig light chains $(\kappa / \lambda)$ & - \\
\hline $\operatorname{Ig} A$ & - \\
\hline $\operatorname{IgD}$ & - \\
\hline $\operatorname{Ig} M$ & - \\
\hline $\mathrm{IgG}$ & - \\
\hline CD10 & - \\
\hline CD19 & ++ \\
\hline CD20 & $+/+++, v$ \\
\hline CD21 & - \\
\hline CD22 & ++ \\
\hline CD23 & - (possible low + on subset) \\
\hline CD24 & - \\
\hline CD32 & - \\
\hline CD38 & $+/-$ \\
\hline CD40 & +++ \\
\hline CD44 & ++ \\
\hline CD45R/B220 & $++/+++$ \\
\hline CD75 & $+/+++, v$ \\
\hline CD77 & - \\
\hline CD79b & $+/++$ \\
\hline CD81 & $++/+++$ \\
\hline CD86 & $+/++$ \\
\hline CD103 & - \\
\hline CD138 & - \\
\hline CD252 & $+/++, v$ \\
\hline Bcl-6 (nuclear) & + \\
\hline \multicolumn{2}{|l|}{ Activation antigens } \\
\hline CD25 & - \\
\hline CD30 & $+/++$ \\
\hline CD70 & $+/++$ \\
\hline CD71 & +++ \\
\hline \multicolumn{2}{|c|}{ T/NK-cell-associated antigens } \\
\hline CD1a & - \\
\hline $\mathrm{CD} 2$ & - \\
\hline $\mathrm{CD} 3$ & - \\
\hline CD4 & - \\
\hline CD5 & - \\
\hline CD7 & - \\
\hline CD8 & - \\
\hline CD26 & $-($ or very low +$)$ \\
\hline CD27 & - \\
\hline CD43 & - \\
\hline CD56 & - \\
\hline CD57 & - \\
\hline CD94 & - \\
\hline CD158a & - \\
\hline CD158b & - \\
\hline CD158e & - \\
\hline \multicolumn{2}{|l|}{ Adhesion molecules } \\
\hline CD18 & $-/+$ \\
\hline CD48 & +++ \\
\hline CD54 (ICAM-1) & +++ \\
\hline CD50 & +++ \\
\hline CD58 & - \\
\hline
\end{tabular}

(table continues)
Table 3 (continued)

\begin{tabular}{|c|c|}
\hline Antigen & DEV expression*† \\
\hline CD102 & $++/+++$ \\
\hline \multicolumn{2}{|c|}{ Myeloid/monocyte/macrophage-associated antigens } \\
\hline CD13 & - \\
\hline CD14 & - \\
\hline CD15 & - \\
\hline CD16 & - \\
\hline CD33 & - \\
\hline CD36 & - \\
\hline CD64 & - \\
\hline CD66b & - \\
\hline CD117 & - \\
\hline CD123 & - \\
\hline CD163 & - \\
\hline CD203c & - \\
\hline \multicolumn{2}{|c|}{ Miscellaneous antigens } \\
\hline EPCAM & - \\
\hline HLA-ABC & - \\
\hline CD34 & - \\
\hline CD45 & ++ \\
\hline CD45 R0 & - \\
\hline CD47 & ++ \\
\hline CD52 & $-($ or low +$)$ \\
\hline CD62L & $+/-$ \\
\hline CD80 & $++/+++$ \\
\hline CD83 & $+/-($ low +$)$ \\
\hline CD90 & - \\
\hline CD95 & ++ \\
\hline CD99 & - \\
\hline CD126 & - \\
\hline CD127 & - \\
\hline CD133 & - \\
\hline CD135 & - \\
\hline CD166 & ++ \\
\hline CD221 & - \\
\hline CD227 & - \\
\hline CD273 & $++/+++$ \\
\hline CD274 & - \\
\hline \multicolumn{2}{|c|}{ Chemokine receptor } \\
\hline CXCR3 & - \\
\hline CXCR4 & $++/+++$ \\
\hline CXCR5 & + \\
\hline CCR5 & - \\
\hline CCR6 & - \\
\hline CCR7 & $-($ or very low + ) \\
\hline \multicolumn{2}{|c|}{ Megakaryocyte antigens } \\
\hline CD61 & - \\
\hline
\end{tabular}

*Degree of antigen expression relative to isotype matched control $(+,++$, +++ is one, two, or three log above isotype-matched control, respectively). ${ }^{\dagger}$ Cell surface expression unless otherwise noted.

DR, antigen D-related; EPCAM, epithelial cell adhesion molecule; HLA, human leukocyte antigen; ICAM-1, intercellular adhesion molecule $1 ; \mathrm{T} / \mathrm{NK}, \mathrm{T} /$ natural killer; $V$, variable.

was not expressed. Finally, CD32 (not expressed or weakly expressed on normal germinal centers, strongly expressed on reactive non-germinal center $\mathrm{B}$ cells) (Figure 2) showed very weak expression when evaluated $(\mathrm{MAI}=0.4)$, 
Table 4 Antigen Expression of LP Events from Flow Cytometry and Morphology-Positive NLPHL Cases

\begin{tabular}{|c|c|c|c|c|}
\hline Antigen & $\begin{array}{l}\text { Mean scored } \\
\text { LP intensity* }\end{array}$ & $\begin{array}{l}\text { No. of } \\
\text { cases }\end{array}$ & $\begin{array}{l}\text { No. of cases positive } \\
\text { (percent positive) }^{\dagger}\end{array}$ & Antigen intensity \\
\hline \multicolumn{5}{|l|}{ B-cell antigens } \\
\hline$\lambda$ & 0 & 10 & $0(0)$ & \\
\hline CD10 & 0 & 12 & $0(0)$ & \\
\hline CD19 & 1.6 & 11 & $10(91)$ & Most at level of small B cells \\
\hline CD38 & 1.5 & 14 & $14(100)$ & \\
\hline CD40 & 2.4 & 19 & $19(100)$ & Mainly higher than small B cells \\
\hline CD75 & 1.8 & 7 & $7(100)$ & Variable expression \\
\hline $\mathrm{Bcl}-6$ & 1.7 & 10 & $10(100)$ & \\
\hline \multicolumn{5}{|l|}{ Adhesion molecules } \\
\hline \multicolumn{5}{|l|}{ B7 molecules } \\
\hline CD80 & 0.2 & 10 & $2(20)$ & \\
\hline CD273 (PD-L2) & 0.4 & 5 & $3(60)$ & When expressed, weak expression \\
\hline CD274 (PD-L1) & 0.2 & 5 & $2(40)$ & When expressed, weak expression \\
\hline CD275 (ICOS-L) & 0.1 & 5 & $1(20)$ & When expressed, weak expression \\
\hline \multicolumn{5}{|l|}{ Other antigens } \\
\hline CD5 & 0 & 18 & $0(0)$ & Evaluated on non-rosetted fraction \\
\hline CD15 & 0 & 14 & $0(0)$ & \\
\hline CD30 & 0.2 & 17 & $5(29)$ & \\
\hline CD45 & 2.7 & 17 & $17(100)$ & \\
\hline CD64 & 0 & 19 & $0(0)$ & \\
\hline
\end{tabular}

*Mean scored intensity is average intensity of antigen expression; each case scored as 0 , not expressed; 1, weak; 2, moderate; or 3, bright expression. 'Expression at any level.

ICAM, intercellular adhesion molecule; ICOS-L, inducible costimulatory ligand; LFA, lymphocyte function-associated antigen; LP, lymphocyte predominant; NLPHL, nodular lymphocyte predominant Hodgkin lymphoma; PD-L1, programmed death-ligand 1; PD-L2, programmed death-ligand 2.

with eight of nine cases showing intensities either less than reactive, non-germinal center $\mathrm{B}$ cells or without any expression. The HRS cells of six CHL cases were examined for the expression of CD32 for comparison with NLPHL; for three cases, the expression of CD32 on the HRS cells was slightly lower than that seen on the non-germinal center $\mathrm{B}$ cells. For the other three cases, the expression of CD32 on the HRS cells was higher than that seen for the non-germinal center B cells.

A single tube combination was designed to evaluate surface $\operatorname{IgH}$ expression ( $\operatorname{Ig} \mathrm{A}, \operatorname{IgD}, \operatorname{IgG}$, and $\operatorname{IgM}$ ) on $\mathrm{LP}$ cells. The six cases evaluated showed, two cases with bright $\mathrm{IgD}$ expression, two cases with no IgH expression, one case with co-expression of $\operatorname{IgM}$ and $\operatorname{IgD}$, and one case with low IgM. No $\operatorname{IgA}$ or IgG expression was identified in the six cases. Four of 10 cases evaluated showed $\kappa$ surface light chain restriction $(\mathrm{MAI}=0.7)$, the other 6 cases showed no surface light chain restriction (Figure 3). For five cases for which both $\operatorname{IgH}$ and light chain were evaluated, the three cases that were positive for $\mathrm{IgH}$ were positive for a light chain $(\kappa)$; conversely, two cases that were negative for $\operatorname{IgH}$ were negative for light chain.

\section{Miscellaneous Antigens}

The T-cell antigen CD5 and the granulocyte marker CD15 (expressed in CHL) were not expressed on putative LP populations. Weak expression of CD30 was, however, occasionally identified (MAI $=0.2 ; 5$ cases positive, 17 cases examined). The activation antigen CD71 (transferrin receptor) was moderately to brightly expressed (MAI $=2.2$ ), often at a level higher than all other cells in the lymph node suspension (and generally higher than that seen on HRS cells from CHL). CD64 (monocyte/macrophage marker) was not expressed, whereas the pan-leukocyte antigen (CD45) was brightly expressed (MAI $=2.7$ ), consistently higher than that seen on the HRS cells of CHL. CD95 (FAS; expressed in CHL) was usually present on LP cells (94\% positive in 16 cases tested); intensity of expression varied from very weak to bright $(\mathrm{MAI}=1.8)$ (Table 4). 

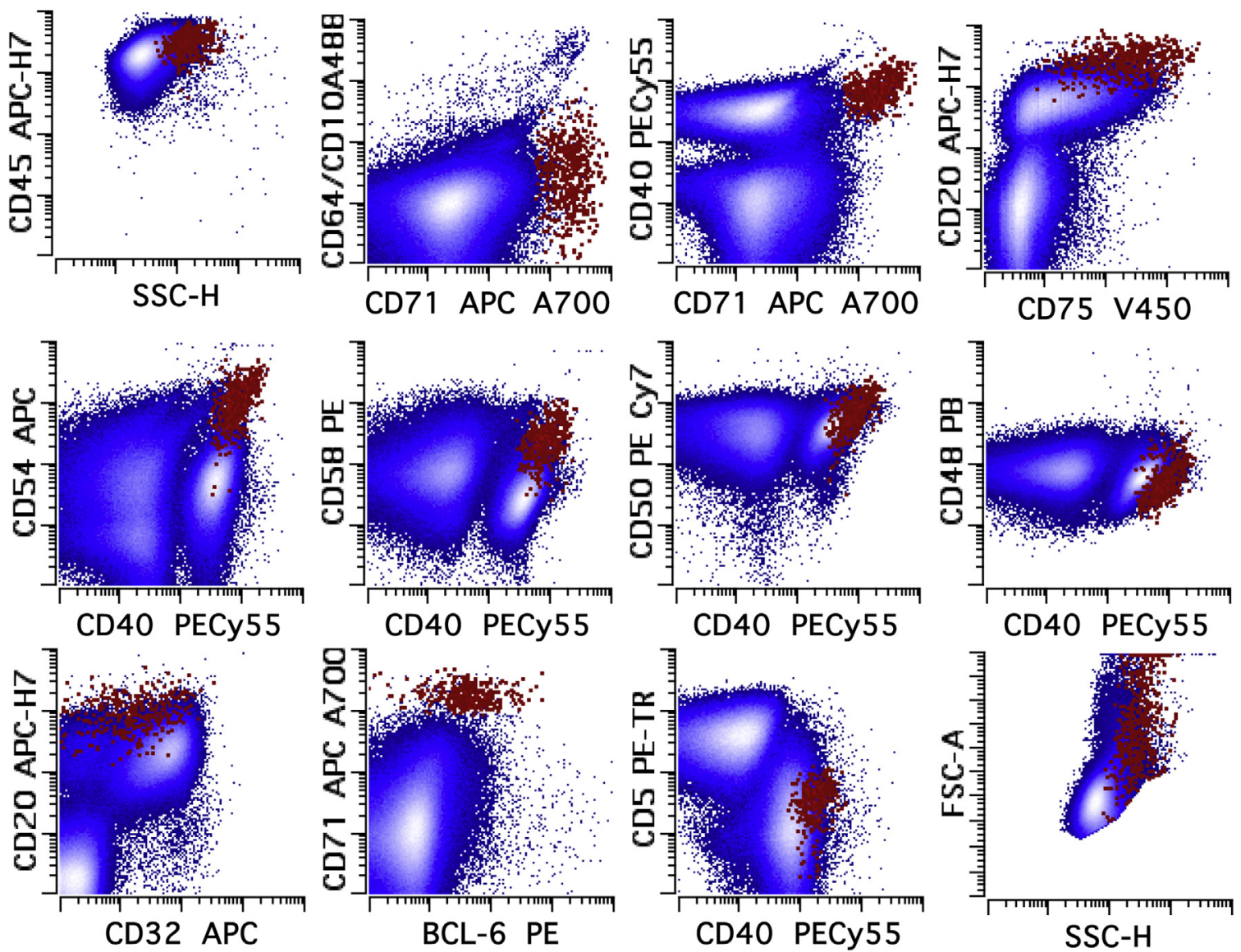

Figure 1 Flow cytometric studies of a lymph node-involved NLPHL. The large (as determined by increased forward and side light scatter compared with the small lymphocytes) neoplastic LP cells express CD20 (bright), CD40 (intermediate to bright), CD48 (low to absent), CD50 (intermediate to bright), CD54 (intermediate to bright), CD58 (intermediate), CD71 (bright), CD75 (variable), and BCL-6 (low to intermediate) without CD5, CD10, or CD64. The immunophenotype identifies a distinct population in multidimensional space with a germinal center immunophenotype. The flow-sorted cells from this case are shown in Figure 4A. The putative neoplastic LP population is colored in red; all other events are in blue. A488, Alexa Fluor 488; APC, allophycocyanin; Cy5.5, cyanine 5.5; Cy7, cyanine 7; FSC, forward scatter; LP, lymphocyte predominant; NLPHL, nodular lymphocyte predominant Hodgkin lymphoma; PB, Pacific Blue; PE, phycoerythrin; SSC, side scatter; TR, Texas Red.

\section{Adhesion Molecules}

Because of their importance in mediating the interaction of HRS cells with T cells, ${ }^{12,19}$ we surveyed expression of these macromolecules on the LP cells. The adhesion molecule CD48 was weakly expressed (MAI $=0.9)$, usually at a level slightly lower than that seen on reactive small B cells. CD50 (intercellular adhesion molecule 3 ) was moderately expressed $(\mathrm{MAI}=1.8)$, at the level of or higher than the other lymphocytes in the lymph node suspension. CD54 was brightly expressed (MAI = 2.6), invariably at a level higher than all other cells in the lymph node suspension. Finally, CD58 showed weak-to-moderate expression $(\mathrm{MAI}=1.7$ ), with some cases showing lower and some cases showing higher expression by the LP cells than the small reactive B cells.

Expression of adhesion molecules (CD48, CD50, CD54, and CD58) was measured in six cases of CHL for comparison with NLPHL. CD54 and CD58 were consistently and brightly expressed on HRS cells of CHL, whereas little to no expression of CD50 and no expression of CD48 were identified.
Light Scatter and DNA Content

LP cells were large (as measured by forward scatter). Side scatter was markedly increased compared with the small lymphocytes such that on a plot showing side scatter on a log scale, the normal lymphocytes and the LP population did not overlap. Nine of 11 cases evaluated for DNA content using DNA binding dye DAPI showed aneuploidy (Figure 3). Of the aneuploid cases, the DNA index for the cells varied from 1.1 to 1.5 , with an average of 1.3 , consistent with hyperdiploidy.

\section{Expression of B7 Family Molecules}

Expression of PD-L1 (CD274), PD-L2 (CD273), and B7H2 (inducible costimulatory ligand; CD275) was evaluated on LP cells in five cases; absent-to-minimal expression was noted on the LP cells from all tested cases for the three antigens (MAIs $=0.2,0.4$, and 0.1, respectively). Six cases of CHL were run for comparison. All six CHL cases showed expression of CD273, whereas five of six cases showed expression of CD274. 

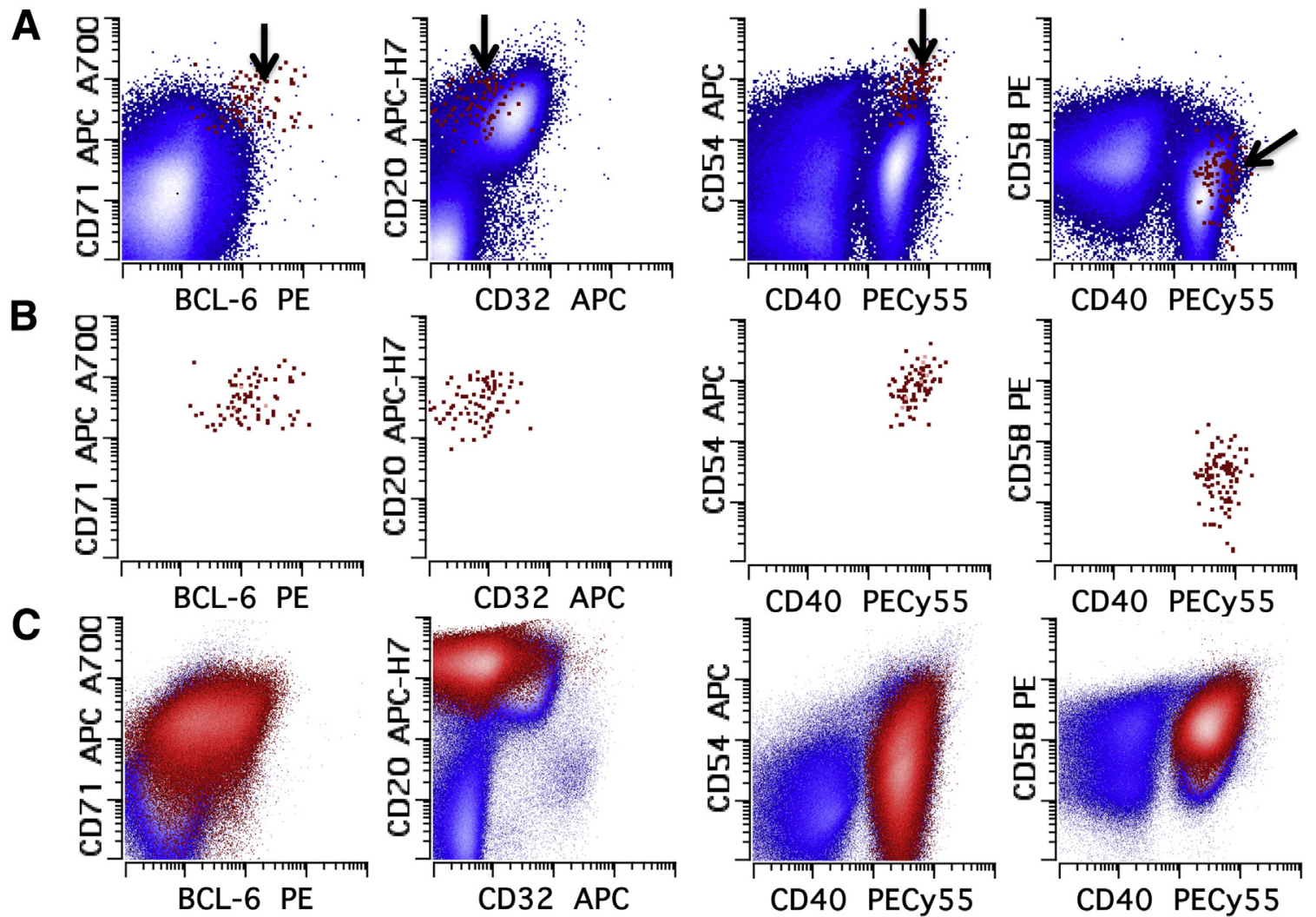

Figure 2 Comparison of a lymph node involved by NLPHL with normal germinal center cells. The putative LP population is identified with arrows (A), in isolation (B) and compared with normal germinal center cells from a tonsil (C). Both the LP cells and germinal center cells have expression of BCL-6 (with increased expression by LP cells relative to germinal center cells) and decreased expression of $C D 32$ (relative to the normal $C D 20^{+}$non-germinal center $B$ cells). The LP cells have increased expression of CD54 and decreased expression CD58 relative to the normal germinal center cells. The LP (A and B) and germinal center (C) population are in red; all other events are in blue. A700, Alexa Fluor 700; APC, allophycocyanin; Cy5.5, cyanine 5.5; LP, lymphocyte predominant; NLPHL, nodular lymphocyte predominant Hodgkin lymphoma; PE, phycoerythrin.

\section{Evaluation of Consensus Tubes for Identification of LP Cells}

Two tubes (Table 2) were designed to identify LP cells in lymph nodes with high specificity and sensitivity. Both tubes used $\mathrm{CD} 20, \mathrm{CD} 38, \mathrm{CD} 40, \mathrm{CD} 54$, and $\mathrm{CD} 71$ to identify the LP cells and CD5, CD10, and CD64 to exclude other events. The first tube also included CD32 and CD75 to evaluate the expression of these antigens on LP cells, and CD5 and CD45 to evaluate for rosette formation. The second tube evaluated DNA content (using DAPI) and nuclear expression of BCL-6. All 7 NLPHL cases evaluated ( 1 case was not among the 19 described above) demonstrated convincing LP populations in both consensus tubes. Evaluation of 94 tissues diagnosed as CHL (9 cases), reactive (30 cases), or B-cell non-Hodgkin lymphoma (55 cases) (Table 5) did not identify an LP-like population in either tube for 91 cases (sensitivity, 100\%; specificity, 96.8\%). An LP-like population was present in one of two tubes for two cases and both tubes for one case; the morphologic diagnosis for all three misclassified cases was diffuse large B-cell lymphoma, not otherwise specified (DLBCL, NOS).
FCCS of LP Cells from Lymph Nodes Involved by NLPHL

To evaluate the morphologic structure of the LP populations identified by flow cytometry and to investigate the preparative utility of this technique, we purified LP cells from six lymph nodes involved by NLPHL with FCCS (Figure 4). Representative photomicrographs of cytocentrifuge preparations of the sorted LP cell populations confirm that the sorted cells have the cytomorphologic features of LP cells (cytomorphology of five of six cases shown). Two cases demonstrated the presence of occasional LP cell-T-cell rosettes. Rosettes were not observed in the four other sorted cases. Sorted cells were evaluated for purity by sorting the previous sorted cells. Purities obtained by FCCS nominally ranged from $56 \%$ to $82 \%$ (Table 6).

\section{Discussion}

This study provides the identification and characterization of LP cells from NLPHL by flow cytometry. Evidence that the cells identified by flow cytometry represent authentic LP cells includes i) cells identified by flow cytometry (Table 4) 

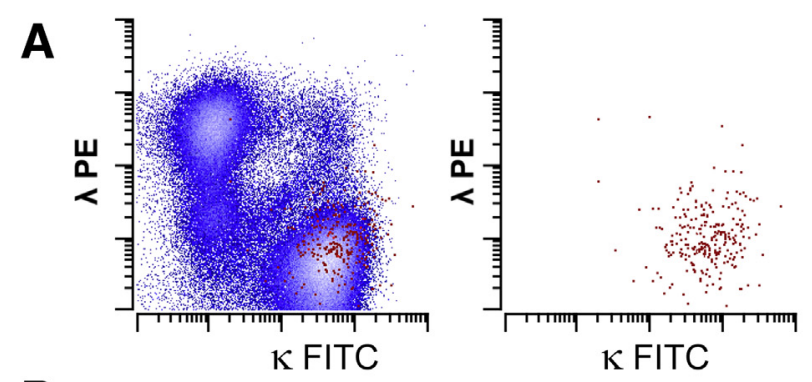

B

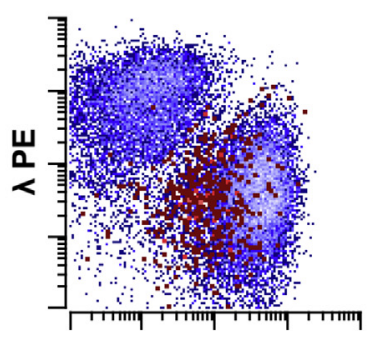

$\kappa \mathrm{APC}$

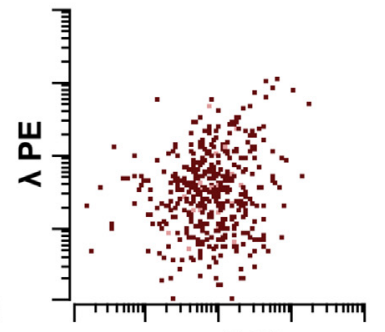

C
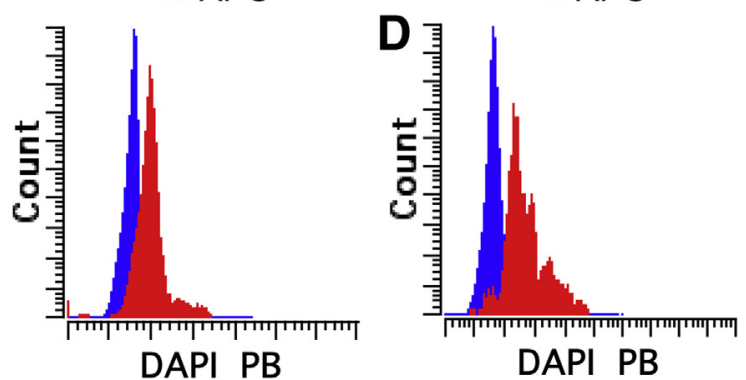

Figure 3 Representative examples of clonality and aneuploidy of LP cells by flow cytometry. Examples of $\kappa$ surface light chain-restricted LP populations (A and $\mathbf{B}$ ) and aneuploidy (C and $\mathbf{D})$ from involved lymph nodes. The LP population was gated with expression of $C D 20, C D 40$, and CD71 (A), CD20, CD40, CD71, and CD95 (B), Bcl-6, CD20, CD40, and increased side light scatter and the absence of expression of CD5, CD10, or CD64 (C and D). Measured DNA indices for panels $\mathbf{C}$ and $\mathbf{D}$ were 1.3 and 1.5, respectively. The LP population is in red; all other events are in blue. APC, allophycocyanin; FITC, fluorescein isothiocyanate; LP, lymphocyte predominant; PB, Pacific Blue; PE, phycoerythrin.

have an immunophenotype that matches (with minor exceptions) that seen with the NLPHL cell line DEV (Table 3) and by immunohistochemistry of $\mathrm{NLPHL}^{1-3}$; ii) cells are aneuploid as measured by ploidy experiments (Figure 3); iii) cells purified by FCCS have the morphologic structure expected for LP cells, displaying multilobated frankly malignant popcorn characteristics (Figure 4); iv) two of the NLPHL cases transformed to large B-cell lymphoma (one case to DLBCL, NOS; one case to T-cell/histiocyte-rich large B-cell lymphoma); in both cases, the transformed lymphoma cells had immunophenotypes identical to the LP populations (data not shown); and v) evaluation of surface light chain expression by flow cytometry suggests these LP populations are abnormal as evidenced by $\kappa$ light chain restriction (Figure 3) or lack of surface light chain. ${ }^{30}$

LP cells in tissues have a unique immunophenotype, being that of an abnormal germinal center $\mathrm{B}$ cell with expression of $\mathrm{CD} 20,{ }^{1-3} \mathrm{CD} 40,{ }^{22,23} \mathrm{CD} 75,{ }^{26}$ and Bcl- $6^{1,3}$ but without the
Table 5 Diagnoses for Specimens Used in Evaluating Consensus NLPHL Tubes

\begin{tabular}{lr}
\hline Diagnosis & No. \\
\hline Reactive tissues & 30 \\
26 reactive follicular hyperplasias, 1 case of & \\
$\quad$ sarcoidosis, 1 case of reactive tissue with & \\
Actinomyces, 1 benign tissue removed for treatment, & \\
1 benign lymph node with focal necrotizing & \\
$\quad$ lymphadenitis & 19 \\
Follicular lymphoma & 18 \\
DLBCL, NOS & 9 \\
Classical Hodgkin lymphoma & 7 \\
Marginal zone & 4 \\
CLL/SLL & 3 \\
Mantle cell lymphoma & 2 \\
B-cell lymphoma, NOS & 1 \\
Splenic marginal zone lymphoma & 1 \\
\hline PMLBCL & \\
\hline
\end{tabular}

CLL, chronic lymphocytic leukemia; DLBCL, diffuse large B-cell lymphoma; NLPHL, nodular lymphocyte predominant Hodgkin lymphoma; NOS, not otherwise specified; PMLBCL, primary mediastinal large B-cell lymphoma; SLL, small lymphocytic lymphoma.

germinal center marker $\mathrm{CD} 10^{3,27}$ or T-cell antigens. Interestingly, in paraffin sections when light chains are expressed, the cells are usually $\kappa$ light chain restricted. ${ }^{24,25}$ Similar results were seen in the present study, showing $\kappa$ surface light chain restriction in 4 of 10 cases and absent surface light chain in the other 6 cases. The putative LP cells by flow cytometry showed expression of CD19 and CD20 (usually at the level of the reactive small $\mathrm{B}$ cells), bright expression of CD40 (similar to that observed in CHL), and Bcl-6. LP cells did not express CD5, CD10, CD15, or CD64, with only minimal CD30 identified. As expected, the putative LP cells were large (measured by forward light scatter).

For the six cases evaluated, the LP cells of two cases demonstrated bright surface expression of IgD, one case coexpressed $\operatorname{IgD}$ and $\operatorname{IgM}$, one case expressed $\operatorname{IgM}$, and two cases were negative for $\operatorname{IgH}$. No surface $\operatorname{IgG}$ or $\operatorname{IgA}$ expression was identified. Prakash et $\mathrm{al}^{31}$ reported that IgD-expressing LP cells (27\% of NLPHL in their cohort) may constitute a unique subset of NLPHL with younger age at presentation (average age, 21 years), although no followup data were available for these cases. Although our case series is small, the three patients who developed NLPHL with IgD + LP cells in our series were older than that seen in the aforementioned study (average age, 38 years). For our cases for which IgH was evaluated, clinical outcome data were available for five cases. Two cases with transformation to large B-cell lymphoma showed expression of $\operatorname{IgD}$ [at 8 (IgD only) and 98.5 (IgM and $\operatorname{IgD}$ ) months]. One case that recurred after 228 months showed IgM expression. No evidence of progression was noted in one IgD- and one IgH-negative case. Although the number of cases is small, given transformation to large B-cell lymphoma is reported in only $3 \%$ to $5 \%$ of NLPHL overall, ${ }^{32}$ these results raise the 

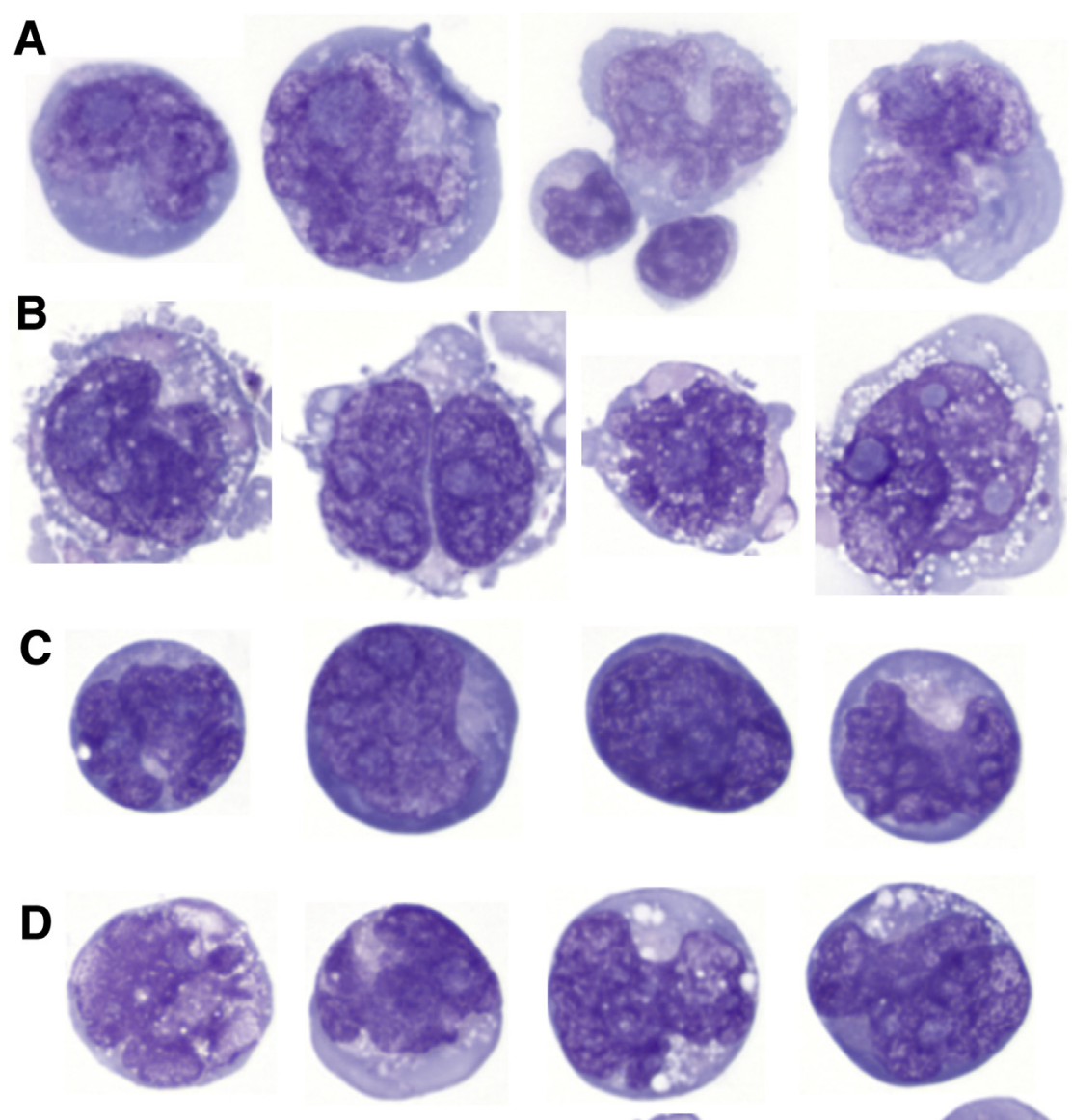

E
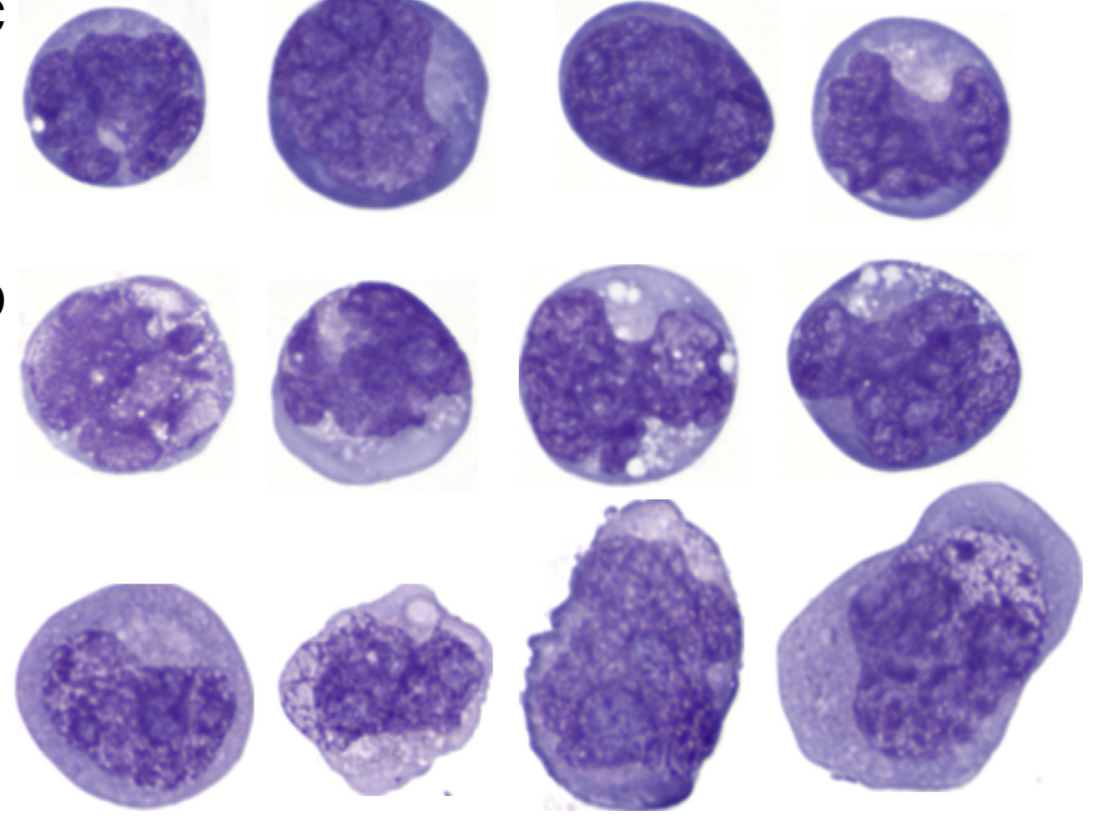

Figure 4 Composite of cytomorphology of LP cells from lymph nodes purified by FCCS. Five FCCS experiments from five cases are shown. A sixth case (not shown) was also subjected to FCCS, with the LP cells also showing appropriate cytomorphology. Occasional T-cell-LP cell rosettes were identified with cases $\mathbf{A}$ (third cell from the left) and $\mathbf{E}$ (rosettes not shown) with none identified with the other cases. The cells are large compared with normal reactive lymphocytes (rosetted lymphocytes seen in A, third cell from the left) and have polylobated nuclear structure consistent with LP cells. Images obtained with Leica DM1000, Leica DFC290 digital microscope camera, and processed with Photoshop CS5 (Adobe Systems, Mountain View, CA) to assemble collage of cells. Flow cytometric combinations used for the FCCS experiments are shown in Materials and Methods. Original magnification, $\times 1000($ A-E). FCCS, flow cytometric cell sorting; LP, lymphocyte predominant. possibility that $\operatorname{IgD}$ or $\operatorname{IgD}$ and $\operatorname{IgM}$ expression suggests a worse prognosis. Supporting this conclusion, Sohani et $\mathrm{al}^{33}$ have demonstrated (in a small number of cases) that NLPHL with atypical $\mathrm{T}$ cells are more likely to recur and that these

Table 6 Purity and Percentage of LP Cells Collected from Six Lymph Nodes Involved by NLPHL

\begin{tabular}{lcll}
\hline $\begin{array}{l}\text { Experiment } \\
\text { no. }^{*}\end{array}$ & $\begin{array}{l}\text { No. of LP } \\
\text { cells sorted }\end{array}$ & $\begin{array}{l}\text { Percentage of LP } \\
\text { cells sorted }^{\dagger}\end{array}$ & Purity (\%) \\
\hline 1 & 964 & ND & ND \\
2 & 1622 & 0.1 & 77.1 \\
3 & 1045 & 0.04 & 72.7 \\
4 & 1560 & 0.03 & 81.6 \\
5 & 2270 & 0.07 & 57.1 \\
6 & 268 & ND & 55.6 \\
\hline
\end{tabular}

*Experiments 1 to 5 correspond to the displayed cases shown in Figure 4. ${ }^{\dagger}$ Total number of LP cells sorted/total number of cells sorted.

LP, lymphocyte predominant; ND, not determined; NLPHL, nodular lymphocyte predominant Hodgkin lymphoma. cases are more likely to show LP cells expressing IgD. In addition, for DLBCL, NOS, IgH expression is predictive of outcome with $\mathrm{IgD} / \mathrm{IgM}$ cases having a worse prognosis. ${ }^{34}$ More extensive studies of $\mathrm{IgH}$ expression and outcome in NLPHL are warranted.

Nine of 11 cases evaluated demonstrated that the putative LP cells were aneuploid. In all nine cases, the LP cells showed a net gain of DNA (DNA indices varied from 1.1 to 1.5; mean, 1.3). Although few cytogenetic studies of NLPHL have been reported, other workers have found similar findings. In a series of 13 NLPHL cases studied by conventional cytogenetics and fluorescence in situ hybridization, Stamatoullas et al ${ }^{35}$ demonstrated that LP cells were aneuploid and clonal in 12 of 13 cases examined; the neoplastic cells from nine patients were near diploid (46 to 49 chromosomes), whereas hypodiploidy and tetraploidy were identified in the other two cases.

By morphologic examination, LP cells are known to be rosetted by $\mathrm{T}$ cells, but the molecular underpinnings of this 
phenomena have not been investigated. Interestingly, our data suggest less avidity of T cells for LP cells compared with T cells for HRS cells, because few rosettes are identified in cytopreparations made from sorted LP cells (Figure 4) compared with CHL cells that demonstrated numerous rosettes from similar FCCS experiments. ${ }^{12,13}$ Supporting this conclusion and unlike CHL cell lines, ${ }^{12,19}$ DEV does not spontaneously rosette normal $\mathrm{T}$ cells (data not shown). Finally, apparent expression of T-cell antigens is significantly less for NLPHL than for CHL (data not shown), the intensity of which affords a crude estimate of the degree of rosetting in CHL. ${ }^{13}$ We chose to evaluate adhesion molecules that are known to be important in the interaction of HRS with T cells. ${ }^{12,19}$ Our results suggest a role for CD54 (intercellular adhesion molecule 1) in mediating this interaction, because CD54 was consistently and brightly expressed in all cases of NLPHL examined (similar to CHL) and consistently greater than reactive germinal center B cells. CD58 showed weak expression on some cases and may be less important in mediating these interactions; this result is in contrast to reactive germinal centers and to CHL (in six cases) in which CD58 is consistently expressed and clearly plays a role in $\mathrm{T}$ cell-HRS cell interactions. ${ }^{12,19}$ Interestingly, although CD50 (intercellular adhesion molecule 3), known to interact with the same ligand (lymphocyte functionassociated antigen-1) as CD54, was often overexpressed on LP cells, HRS cells showed only low expression. CD48 (low-affinity receptor of CD2 and high-affinity receptor for $2 \mathrm{~B} 4^{36}$ ) showed little expression on either LP or HRS cells. It is tempting to propose that decreased and variable expression of CD58 may be responsible for the decrease in rosetting observed in NLPHL compared with CHL. In prior studies, we and others confirmed the importance of CD54 and CD58 on HRS cells of CHL in mediating the interaction of HRS cells to T cells by using blocking antibodies to disrupt the interactions. ${ }^{12,19}$ Unfortunately, sufficient material was not available to further evaluate these interactions by this approach; consequently, further studies will be required to confirm the importance of these adhesion molecules in contributing to the interaction of T cells with LP cells and to examine how this pattern of adhesion macromolecule expression affects the immune response to LP cells.

PD-1 is expressed on T cells and binds to PD-L1 and PDL2 (on the cancer or antigen-presenting cell) resulting in inhibition for the $\mathrm{T}$ cells during the effector phase of a T-cell response. ${ }^{37}$ Blocking PD-1-PD-L1/PD-L2 interactions may augment tumor immunotherapy. ${ }^{29}$ Although there are conflicting reports regarding PD-L1 expression on LP cells in the literature, ${ }^{28,38}$ the results presented herein suggest such an approach may not be effective in NLPHL because PD-L1 (CD274) and PD-L2 (CD273) are not present on LP cells by flow cytometry ${ }^{28,39}$ and (for at least subset of neoplasms) PD-L1/PD-L2 expression on tumor cells is correlated with anti-PD-1 therapeutic response. ${ }^{40,41}$
$\mathrm{CD} 32$ is a low-affinity $\mathrm{Fc}$ receptor and tends to be expressed at lower levels on B-cell non-Hodgkin lymphoma of germinal center origin. ${ }^{42} \mathrm{By}$ binding $\mathrm{Fc}, \mathrm{CD} 32$ may provide a mechanism of resistance to rituximab therapy. ${ }^{42}$ We evaluated 11 cases of follicular hyperplasia and noted that CD32 is not expressed on T cells, is not expressed or weakly expressed by germinal center B cells, and is strongly expressed on non-germinal center B cells (Figure 2). Similarly, LP cells demonstrated decreased expression of CD32 relative to the non-germinal center $\mathrm{B}$ cells in eight of nine cases examined. Six CHL cases demonstrated overall higher levels of CD32. Although these results suggest efficacy of rituximab in NLPHL, these studies argue for correlating CD32 expression with rituximab efficacy in NLPHL in future clinical trials.

This work demonstrates that NLPHL can be immunophenotyped by flow cytometry. We identified an LP population by flow cytometry in 19 of 26 cases examined (73\%). Furthermore, a set of consensus tubes (Table 2) identified an LP population in both tubes from all seven subsequent test cases of NLPHL (100\% sensitivity). Evaluation of 94 tissues diagnosed as B-cell lymphoma (55 cases) (Table 5), reactive (30 cases), or CHL (9 cases) did not identify an LP-like population in 91 cases $(96.8 \%$ specificity). We envision the consensus tubes to be primarily useful in suggesting a diagnosis of NLPHL in the following two clinical settings: when a reactive CD4/CD8 co-expressing T-cell population suggestive of NLPHL has been identified by flow cytometry ${ }^{43,44}$ and in challenging cases when the morphologic suspicion is NLPHL and additional information is needed to support that impression. Work presented here suggests the consensus tubes would be useful in differentiating NLPHL from CHL and DLBCL, NOS (two entities frequently in the differential diagnosis with NLPHL).

These studies suggest an antibody combination (consensus tube 1) that would be useful for purifying LP cells by FCCS. Because purification of LP cells currently involves the labor-intensive process of microdissection, the method described herein will afford thousands of isolated LP cells in a few hours. In addition, although a formal comparison of microdissection and FCCS has not been described, one study showed twofold to threefold higher yield of single cells with amplifiable DNA from sorted versus microdissected $\mathrm{T}$ cells, ${ }^{45}$ suggesting sorted cells may be more amenable to subsequent genetic studies.

Herein, we report the characterization of LP cells from NLPHL by flow cytometry and FCCS. Further studies are required to fully characterize the diagnostic utility of the two-tube consensus tube assay and to determine whether the differences in expression of CD32, CD50, CD273, and CD274 between CHL and NLPHL can distinguish these lymphomas by immunohistochemistry. Another intriguing question is whether the neoplastic cells of T-cell/histiocyterich large B-cell lymphoma can be immunophenotyped and purified by flow cytometry and FCCS, given the 
immunophenotypic similarity to NLPHL. ${ }^{4,46-49}$ These questions are being investigated in our laboratory.

\section{Acknowledgments}

\section{We thank Dr. Lori Soma for her critical review of the} manuscript.

J.R.F. conceived of the project; J.R.F. and B.L.W. designed the experiments; A.T. performed all the experiments; J.R.F. and A.T. analyzed the data; and J.R.F. wrote the manuscript. All authors read and approved the manuscript.

\section{References}

1. Poppema S, Delsol G, Pileri SA, Stein H, Swerdlow SH, Warnke RA, Jaffe ES: Nodular lymphocyte predominant Hodgkin lymphoma. Edited by Swerdlow SH, Campos E, Harris NL, Jaffe ES, Pileri SA, Stein H, Thiele J, Vardiman JW. In WHO Classification of Tumours of Haematopoietic and Lymphoid Tissues. Lyon, France: IARC Press, 2008. pp. 323-325

2. Schmitz R, Stanelle J, Hansmann ML, Kuppers R: Pathogenesis of classical and lymphocyte-predominant Hodgkin lymphoma. Annu Rev Pathol 2009, 4:151-174

3. Uherova P, Valdez R, Ross CW, Schnitzer B, Finn WG: Nodular lymphocyte predominant Hodgkin lymphoma. An immunophenotypic reappraisal based on a single-institution experience. Am J Clin Pathol 2003, 119:192-198

4. Stein H, Delsol G, Pileri SA, Weiss LM, Poppema S, Jaffe ES: Classical Hodgkin Lymphoma, introduction. Edited by Swerdlow SH, Campos E, Harris NL, Jaffe ES, Pileri SA, Stein H, Thiele J, Vardiman JW. In WHO Classification of Tumours of Haematopoietic and Lymphoid Tissues. Lyon, France: IARC Press, 2008. pp. 326-329

5. Harris NL: Hodgkin's lymphomas: classification, diagnosis, and grading. Semin Hematol 1999, 36:220-232

6. Harris NL: Hodgkin's disease: classification and differential diagnosis. Mod Pathol 1999, 12:159-175

7. Wood BL, Borowitz MJ: The flow cytometric evaluation of hematopoietic neoplasia. Edited by McPherson RA, Pincus MR. In Henry's Clinical Diagnosis and Management by Laboratory Methods. Philadelphia, PA: Saunders Elsevier, 2011. pp. 656-673

8. Givan AL: Flow cytometry: an introduction. Methods Mol Biol 2011, 699:1-29

9. Fromm JR, Wood BL: A six-color flow cytometry assay for immunophenotyping classical Hodgkin lymphoma in lymph nodes. Am J Clin Pathol 2014, 141:388-396

10. Fromm JR, Thomas A, Wood BL: Flow cytometry can diagnose classical hodgkin lymphoma in lymph nodes with high sensitivity and specificity. Am J Clin Pathol 2009, 131:322-332

11. Wu D, Wood BL, Fromm JR: Flow cytometry for non-Hodgkin and classical Hodgkin lymphoma. Methods Mol Biol 2013, 971:27-47

12. Fromm JR, Kussick SJ, Wood BL: Identification and purification of classical Hodgkin cells from lymph nodes by flow cytometry and flow cytometric cell sorting. Am J Clin Pathol 2006, 126:764-780

13. Fromm JR, Wood BL: Strategies for immunophenotyping and purifying classical Hodgkin lymphoma cells from lymph nodes by flow cytometry and flow cytometric cell sorting. Methods 2012, 57: 368-375

14. Stein H: Hodgkin lymphoma-introduction. Edited by Swerdlow SH, Campos E, Harris NL, Jaffe ES, Pileri SA, Stein H, Thiele J, Vardiman JW. In WHO Classification of Tumours of Haematopoietic and Lymphoid Tissues. Lyon, France: IARC Press, 2008. pp. 322
15. Kadin ME, Newcom SR, Gold SB, Stites DP: Letter: Origin of Hodgkin's cell. Lancet 1974, 2:167-168

16. Payne SV, Jones DB, Wright DH: Reed-Sternberg-cell/lymphocyte interaction. Lancet 1977, 2:768-769

17. Payne SV, Newell DG, Jones DB, Wright DH: The Reed-Sternberg cell/lymphocyte interaction: ultrastructure and characteristics of binding. Am J Pathol 1980, 100:7-24

18. Stuart AE, Williams AR, Habeshaw JA: Rosetting and other reactions of the Reed-Sternberg cell. J Pathol 1977, 122:81-90

19. Sanders ME, Makgoba MW, Sussman EH, Luce GE, Cossman J, Shaw S: Molecular pathways of adhesion in spontaneous rosetting of T-lymphocytes to the Hodgkin's cell line L428. Cancer Res 1988, 48: $37-40$

20. Poppema S, De Jong B, Atmosoerodjo J, Idenburg V, Visser L, De Ley L: Morphologic, immunologic, enzymehistochemical and chromosomal analysis of a cell line derived from Hodgkin's disease. Evidence for a B-cell origin of Sternberg-Reed cells. Cancer 1985, 55: 683-690

21. Drexler HG, Minowada J: Hodgkin's disease derived cell lines: a review. Hum Cell 1992, 5:42-53

22. Carbone A, Gloghini A, Pinto A: CD40: a sensitive marker of ReedSternberg cells. Blood 1996, 87:4918-4919

23. Carbone A, Gloghini A, Gattei V, Aldinucci D, Degan M, De Paoli P, Zagonel V, Pinto A: Expression of functional CD40 antigen on ReedSternberg cells and Hodgkin's disease cell lines. Blood 1995, 85: 780-789

24. Schmid C, Sargent C, Isaacson PG: L and H cells of nodular lymphocyte predominant Hodgkin's disease show immunoglobulin light-chain restriction. Am J Pathol 1991, 139:1281-1289

25. Stoler MH, Nichols GE, Symbula M, Weiss LM: Lymphocyte predominance Hodgkin's disease. Evidence for a kappa light chainrestricted monotypic B-cell neoplasm. Am J Pathol 1995, 146: $812-818$

26. Torlakovic E, Torlakovic G: B-cell markers in lymphocyte predominance Hodgkin disease. Arch Pathol Lab Med 2002, 126:862-863

27. Gruss HJ, Kadin ME: Pathophysiology of Hodgkin's disease: functional and molecular aspects. Baillieres Clin Haematol 1996, 9: 417-446

28. Chen BJ, Chapuy B, Ouyang J, Sun HH, Roemer MG, Xu ML, Yu H, Fletcher CD, Freeman GJ, Shipp MA, Rodig SJ: PD-L1 expression is characteristic of a subset of aggressive B-cell lymphomas and virusassociated malignancies. Clin Cancer Res 2013, 19:3462-3473

29. Ribas A: Tumor immunotherapy directed at PD-1. N Engl J Med 2012, $366: 2517-2519$

30. Li S, Eshleman JR, Borowitz MJ: Lack of surface immunoglobulin light chain expression by flow cytometric immunophenotyping can help diagnose peripheral B-cell lymphoma. Am J Clin Pathol 2002, 118:229-234

31. Prakash S, Fountaine T, Raffeld M, Jaffe ES, Pittaluga S: IgD positive L\&H cells identify a unique subset of nodular lymphocyte predominant Hodgkin lymphoma. Am J Surg Pathol 2006, 30:585-592

32. Huang JZ, Weisenburger DD, Vose JM, Greiner TC, Aoun P, Chan WC, Lynch JC, Bierman PJ, Armitage JO: Diffuse large B-cell lymphoma arising in nodular lymphocyte predominant Hodgkin lymphoma: a report of 21 cases from the Nebraska Lymphoma Study Group. Leuk Lymphoma 2004, 45:1551-1557

33. Sohani AR, Jaffe ES, Harris NL, Ferry JA, Pittaluga S, Hasserjian RP: Nodular lymphocyte-predominant hodgkin lymphoma with atypical T cells: a morphologic variant mimicking peripheral T-cell lymphoma. Am J Surg Pathol 2011, 35:1666-1678

34. Ruminy P, Etancelin P, Couronne L, Parmentier F, Rainville V, Mareschal S, Bohers E, Burgot C, Cornic M, Bertrand P, Lenormand B, Picquenot JM, Jardin F, Tilly H, Bastard C: The isotype of the $\mathrm{BCR}$ as a surrogate for the $\mathrm{GCB}$ and $\mathrm{ABC}$ molecular subtypes in diffuse large B-cell lymphoma. Leukemia 2011, 25:681-688

35. Stamatoullas A, Picquenot JM, Dumesnil C, Ruminy P, Penther D, Bertrand P, Courel MN, Maisonneuve C, Francois A, Gaulard P, 
Tilly H, Bastard C: Conventional cytogenetics of nodular lymphocytepredominant Hodgkin's lymphoma. Leukemia 2007, 21:2064-2067

36. Elishmereni M, Levi-Schaffer F: CD48: a co-stimulatory receptor of immunity. Int J Biochem Cell Biol 2011, 43:25-28

37. Saresella M, Rainone V, Al-Daghri NM, Clerici M, Trabattoni D: The PD-1/PD-L1 pathway in human pathology. Curr Mol Med 2012, 12: 259-267

38. Dorfman DM, Brown JA, Shahsafaei A, Freeman GJ: Programmed death-1 (PD-1) is a marker of germinal center-associated T cells and angioimmunoblastic T-cell lymphoma. Am J Surg Pathol 2006, 30: 802-810

39. Yamamoto R, Nishikori M, Kitawaki T, Sakai T, Hishizawa M, Tashima M, Kondo T, Ohmori K, Kurata M, Hayashi T, Uchiyama T: PD-1-PD-1 ligand interaction contributes to immunosuppressive microenvironment of Hodgkin lymphoma. Blood 2008, 111: 3220-3224

40. Taube JM, Klein A, Brahmer JR, Xu H, Pan X, Kim JH, Chen L, Pardoll DM, Topalian SL, Anders RA: Association of PD-1, PD-1 ligands, and other features of the tumor immune microenvironment with response to anti-PD-1 therapy. Clin Cancer Res 2014, 20: 5064-5074

41. Topalian SL, Hodi FS, Brahmer JR, Gettinger SN, Smith DC, McDermott DF, Powderly JD, Carvajal RD, Sosman JA, Atkins MB, Leming PD, Spigel DR, Antonia SJ, Horn L, Drake CG, Pardoll DM, Chen L, Sharfman WH, Anders RA, Taube JM, McMiller TL, Xu H, Korman AJ, Jure-Kunkel M, Agrawal S, McDonald D, Kollia GD, Gupta A, Wigginton JM, Sznol M: Safety, activity, and immune correlates of anti-PD-1 antibody in cancer. N Engl J Med 2012, 366: $2443-2454$
42. Lim SH, Vaughan AT, Ashton-Key M, Williams EL, Dixon SV, Chan HT, Beers SA, French RR, Cox KL, Davies AJ, Potter KN, Mockridge CI, Oscier DG, Johnson PW, Cragg MS, Glennie MJ: Fc gamma receptor IIb on target $\mathrm{B}$ cells promotes rituximab internalization and reduces clinical efficacy. Blood 2011, 118:2530-2540

43. Rahemtullah A, Reichard KK, Preffer FI, Harris NL, Hasserjian RP: A double-positive $\mathrm{CD} 4+\mathrm{CD} 8+\mathrm{T}$-cell population is commonly found in nodular lymphocyte predominant Hodgkin lymphoma. Am J Clin Pathol 2006, 126:805-814

44. Rahemtullah A, Harris NL, Dorn ME, Preffer FI, Hasserjian RP: Beyond the lymphocyte predominant cell: $\mathrm{CD} 4+\mathrm{CD} 8+\mathrm{T}$-cells in nodular lymphocyte predominant Hodgkin lymphoma. Leuk Lymphoma 2008, 49:1870-1878

45. Roers A, Montesinos-Rongen M, Hansmann ML, Rajewsky K, Kuppers R: Amplification of TCRbeta gene rearrangements from micromanipulated single cells: $\mathrm{T}$ cells rosetting around Hodgkin and Reed-Sternberg cells in Hodgkin's disease are polyclonal. Eur J Immunol 1998, 28:2424-2431

46. Pittaluga S, Jaffe ES: T-cell/histiocyte-rich large B-cell lymphoma. Haematologica 2010, 95:352-356

47. Abramson JS: T-cell/histiocyte-rich B-cell lymphoma: biology, diagnosis, and management. Oncologist 2006, 11:384-392

48. Tousseyn T, De Wolf-Peeters C: T cell/histiocyte-rich large B-cell lymphoma: an update on its biology and classification. Virchows Arch 2011, 459:557-563

49. Fraga M, Sanchez-Verde L, Forteza J, Garcia-Rivero A, Piris MA: T-cell/histiocyte-rich large B-cell lymphoma is a disseminated aggressive neoplasm: differential diagnosis from Hodgkin's lymphoma. Histopathology 2002, 41:216-229 